\title{
Wizyta polskich naukowców w Szczecinie i w Wolinie w 1935 roku*
}

Zarys treści: Artykuł dotyczy przyczyn, przygotowań oraz przebiegu i rezultatów wyprawy polskich naukowców z Poznania w październiku 1935 r. celem zapoznania się z niemieckimi pracami archeologicznymi w Wolinie. Artykuł oparty jest na niewykorzystywanych dotychczas materiałach źródłowych. Wyprawa została przedstawiona w kontekście ówczesnych stosunków politycznych i naukowych między Polską a Niemcami.

Content outline: The paper deals with the causes, preparations, course and results of the expedition of Polish scholars from Poznan in October 1935 with the aim of getting acquainted with the German archaeological excavations on Wolin. The paper is based on so far unused source materials. The expedition is presented within the context of the political and scholarly relations between Poland and Germany.

Słowa kluczowe: archeologia, Wolin, stosunki polsko-niemieckie

Keywords: archaeology, Wolin, Polish-German relations

Pierwsze wykopaliska archeologiczne w Wolinie przeprowadzono jeszcze w pierwszej połowie XIX w. W kolejnym półwieczu działał tam słynny niemiecki antropolog Rudolf Virchow, a u schyłku tego stulecia szczeciński prehistoryk Adolf Stubenrauch. Do badań terenowych w tym mieście powrócono wraz z narastaniem dyskusji o lokalizacji oraz znaczeniu Winety i Jomsborga ${ }^{1} \mathrm{w}$ latach trzydziestych XX w. ${ }^{2}$ Systematyczne wykopaliska rozpoczęto w 1934 r. ze środków Notgemeinschaft der Deutschen Wissenschaft i Archäologisches Institut des Deutsches Reiches, przerwała je zaś II wojna światowa. Objęły one rejon Starego Miasta, Srebrnego Wzgórza i cmentarzyska na Młynówce 3 . Ponieważ sprawa Wolina i jego związków

* Część kwerend do przygotowania niniejszego artykułu wykonałem w ramach grantu pt. Polska i Pomorze w kształtowaniu cywilizacji europejskiej (od słowiańskich plemion do przełomu XII i XIII w.), NPRH, nr 12H 130590 820, kierowanego przez prof. dr. hab. Stanisława Rosika na Uniwersytecie Wrocławskim.

${ }^{1} \mathrm{O}$ tzw. Wineta-Frage zob. P. Migdals ki, Słowiańszczyzna północno-zachodnia w historiografii polskiej, niemieckiej i duńskiej, Wodzisław Śląski 2019 (w druku), s. 260-262, 283-287.

${ }^{2}$ Zachowana korespondencja na temat planowanych badań sięga 1931 r., zob. Archiwum Działu Archeologii Muzeum Narodowego w Szczecinie (dalej cyt.: ADAMNSz), teczka nr 1758 i 1765 .

${ }^{3}$ Historia badań przedwojennych nie doczekała się dotąd szczegółowej analizy. W dotychczas ukazujących się pracach o wykopaliskach w Wolinie były one jedynie wzmiankowane. 
z Jomsborgiem oraz początkami państwa polskiego była żywotnie istotna także dla polskich badaczy (jak Stanisław Zakrzewski, Kazimierz Tymieniecki, Józef Widajewicz, Leon Koczy), którzy już podczas I wojny światowej zaczęli przesuwać centrum wydarzeń związanych z początkami panowania Mieszka I właśnie na Pomorze Zachodnie, nie dziwi zatem ich chęć przyjazdu na rekonesans badawczy do Wolina. Dzieje tej wyprawy nie cieszyły się dotychczas większym zainteresowaniem badaczy: historiografii, historii archeologii czy stosunków polsko-niemieckich. W ogóle nie dostrzegli jej historycy archeologii ani biografowie zapraszanych uczonych ${ }^{4}$. Wspomnieli ją natomiast historycy Bernard Piotrowski ${ }^{5}$ oraz niedawno Małgorzata Mastalerz-Krystjańczuk i Włodzimierz Stępiński ${ }^{6}$. Zdecydowanie więcej miejsca poświęcił wizycie w swoim reportażu historycznym Kazimierz Błahij oraz Błażej Stanisławski w studium przygotowanym na podstawie artykułów z Roczników Historycznych ${ }^{8}$. Dopiero ostatnio pojawiły się prace omawiające krótko przyjazd Polaków do Wolina z wykorzystaniem niektórych źródeł archiwalnych ${ }^{9}$. Warto tu odnotować,

Jedynymi pracami opartymi na materiale archiwalnym są artykuły F. B i e r m a n n, A Slavic or a Viking town? The excavations at Wolin 1934/41 and their contemporary interpretation, w: Scandinavian Culture in Medieval Poland, Wrocław 2013, s. 179-191; W. F i 1 i p o w i a k, M. Gi e r k e, K. K o k or a, M. Kow a ls k a, Zaginiona dokumentacja z przedwojennych badań archeologicznych w Wolinie, w: Kościoły w dobie chrystianizacji, Szczecin 2016 (Wolińskie Spotkania Mediewistyczne III), s. 13-30.

4 J. Ko strzew ski, Dzieje polskich badań prehistorycznych, Poznań 1949; J. Gą s s o w s ki, Z dziejów polskiej archeologii, Warszawa 1970; J. E. K a c z m a r e k, Organizacja badań i ochrony zabytków archeologicznych w Poznaniu (1720-1958), Poznań 1996; S. K. K o zło w s ki, Kwiat królestwa. Archeologów polskich pokolenie trzecie, Warszawa-Łódź 2015; t e nże, Włodzimierz Antoniewicz, profesor z Warszawy, Warszawa 2009; J. E. K a c z m a r e k, A. Pr i n k e, Żywot długi, pracowity i spełniony. Profesor Józef Kostrzewski (1885-1969) - prehistoryk, patriota, Europejczyk, Poznań [w druku] (panu dr. Andrzejowi Prinke dziękuję za udostępnienie książki przed publikacją; wyprawa wspomniana jest jedynie za pamiętnikiem J. Kostrzewskiego); Kazimierz Tymieniecki (1887-1968). Dorobek i miejsce w mediewistyce polskiej, Poznań 1990. Brak informacji także w biografiach archeologa Leona Kozłowskiego: M. K o zło w ski, Sprawa premiera Leona Kozłowskiego. Zdrajca czy ofiara?, Warszawa 2005; Profesor Leon Kozłowski, red. S. K. Kozłowski, O. Sytnyk, Lwów-Warszawa 2010.

${ }^{5}$ B. P i o tr o w s k i, O Polskę nad Odrą i Bałtykiem. Myśl zachodnia i badania niemcoznawcze Uniwersytetu Poznańskiego, Poznań 1987, s. 76, gdzie zanotowano, że O. Kunkel był ciekaw opinii polskich badaczy.

${ }^{6}$ M. Masta lerz-Kry stj ań c z u k, Pomorze Zachodnie w polskiej nauce, publicystyce i działalności politycznej w latach 1919-1939, Słupsk 2013, s. 55; W. S tę piń s ki, Prasa Pomorza Zachodniego wobec stosunków Rzeszy z II Rzeczpospolitą w latach 1933-1935. Między kontynuacją a zwrotem, w: Deklaracja polsko-niemiecka o niestosowaniu przemocy z dnia 26 stycznia 1934 r. z perspektywy Polski i Europy w siedemdziesiątą rocznicę podpisania, Toruń 2005, s. 294.

${ }^{7}$ K. Bła h ij, Ostatnia tajemnica zatopionych bogów, Warszawa 1971, s. 57-60, 74-78.

${ }^{8}$ B. M. S t a n i s $\nmid$ a w s k i, Jómswikingowie z Wolina-Jómsborga - studium archeologiczne przenikania kultury skandynawskiej na ziemie polskie, Wrocław 2013, s. 72-75.

9 W. S k ó r a, Konsulat Rzeczypospolitej Polskiej w Szczecinie w latach 1925-1939, Słupsk 2001, s. 198-199; A. Lew - M a c h n i a k, Między otwartą wrogością a fasadową przyjaźnią. Heliodor Sztark - polski konsul w niemieckim Szczecinie, Szczecin 2016, s. 45; M. Szukała, Pruskie archiwa państwowe a niemieckie badania wschodnie (deutsche 
że trzy dokumenty związane z wizytą w Wolinie opublikował w 2006 r. Edward Włodarczyk ${ }^{10}$, a wspomnienie o niej znalazło się w napisanym po latach pamiętniku Józefa Kostrzewskiego ${ }^{11}$ oraz w słynnym reportażu Ziemia gromadzi prochy Józefa Kisielewskiego, który ukazał się tuż przed wybuchem drugiej wojny światowej ${ }^{12}$. Badacze niemieccy także nie zwracali większej uwagi na wolińską wizytę. Felix Biermann wskazał zaledwie, że do Wolina w trakcie wykopalisk przybywało wielu uznanych uczonych ${ }^{13}$, z kolei Markus Krzoska w gruntownym studium o Zygmuncie Wojciechowskim (jednym $\mathrm{z}$ animatorów wyprawy) zupełnie ją pomija ${ }^{14}$.

Celem tego artykułu jest zatem przedstawienie na podstawie przede wszystkim zachowanego materiału archiwalnego (z Archiwum Działu Archeologii Muzeum Narodowego w Szczecinie, Archiwum Akt Nowych w Warszawie, Archiwum Państwowego w Szczecinie) oraz przekazów drukowanych przyczyn, organizacji, przebiegu oraz skutków wyprawy polskich badaczy do Szczecina i Wolina jesienią 1935 r.

W 1934 r. przybył na zachodniopomorskie wybrzeże Bałtyku na wakacje Zygmunt Wojciechowski ${ }^{15}$. Po powrocie do Poznania w artykule sprawozdawczym pisał, że spełniło się życzenie Adolfa Hofmeistera o badaniach w Wolinie. Wskazywał, że rozpoczęto je od rynku, gdzie wyniki miały się okazać „rewelacyjne”. Według informacji przekazanej przez ówczesnego studenta archeologii z Greifswaldu, nadzorującego wykopaliska w Wolinie Karla Augusta Wildego ${ }^{16}$, cały woliński kompleks osadniczy miał 3-5 kilometrów długości. W warstwach, które wówczas osiągnięto - datowanych na XI w. - widoczna była bogata osada handlowa, w której zauważalne były wpływy nordyckie. Niemiecki archeolog sugerował, że wolińskimi badaniami warto zainteresować polskich kolegów ${ }^{17}$. Podczas swojej podróży Wojciechowski odwiedził także Szczecin, a w nim - jak wskazuje dalsza korespondencja - też konsulat

Ostforschung) w okresie międzywojennym XX wieku (1918-1939). Między nauką a politycznym zaangażowaniem, Szczecin-Warszawa 2011, s. 151-152.

10 Źródła do kaszubsko-polskich aspektów dziejów Pomorza Zachodniego do roku 1945, red. B. Wachowiak, t. IV: Pomorze Zachodnie okresie od traktatu wersalskiego po klęskę III Rzeszy w 1945 r., wyd. E. Włodarczyk, Poznań-Gdańsk 2006, nr 41-43, s. 97-104.

11 J. K o s tr z e w s k i, Z mego życia. Pamiętnik, Wrocław 1970, s. 205, gdzie wskazanie, że wyprawa odbyła się na zaproszenie prof. Wilhelma Unverzagta. Opracowująca spuściznę po W. Unverzagcie, Susanne Grunwald (której niniejszym dziękuję za tę informację) nie znalazła potwierdzenia słów J. Kostrzewskiego. Warto natomiast wskazać, że prof. W. Unverzagt znał wykopaliska wolińskie, był informowany o nich przez O. Kunkla, a Wolin odwiedził już w 1932 r. Por. korespondencję między O. Kunklem i W. Unverzagtem: ADAMNSz, teczka nr 1758.

12 J. K i s i e lew s k i, Ziemia gromadzi prochy, Warszawa 1990, s. 264.

${ }_{13}$ F. B i e r m a n n, A Slavic or a Viking town?, s. 186.

${ }_{14}$ M. Kr z o s k a, Für ein Polen an Oder und Ostsee. Zygmunt Wojciechowski (1900-1955) als Historiker und Publizist, Osnabrück 2003.

15 Z. W o j c i e c h o w s k i, Kilka słów o Wolinie, Roczniki Historyczne 10, 1934, s. 246; t e n ż e, Jeszcze słowo o Wolinie, Roczniki Historyczne 11, 1935, s. 211.

${ }^{16}$ Karl August Wilde (ur. 1911, zm. w trakcie II wojny światowej), archeolog, doktorat z badań wolińskich uzyskał u W. Petzscha w Greifswaldzie w 1937 r.; zob. H. S c h u b a rt, Die Vorgeschichtsforschung an der Universität Greifswald, w: Festschrift zur 500-Jahrfeier der Universität Greifswald, 17. 10. 1956, t. II, Greifswald 1956, s. 119-120; życiorys (Lebenslauf) zawarty w pracy K. A. W i 1 d e, Die Bedeutung der Grabung Wollin 1934, Stettin 1939, s. 95.

${ }^{17}$ Z. W o j c i e c h o w s k i, Kilka słów, s. 247-248. 
polski. Spotkanie poznańskiego historyka prawa z konsulem Rzeczpospolitej Polskiej w Szczecinie Heliodorem Sztarkiem zaowocowało najprawdopodobniej podjęciem działań przez konsulat. Sztark 23 IX 1934 r. wysłał pismo do Ministerstwa Spraw Zagranicznych w Warszawie, w którym informował, że w Wolinie (,starożytne Jullin - Vinetta[?]") prowadzone są prace wykopaliskowe przez dyrektora szczecińskiego muzeum Ottona Kunkla ${ }^{18}$. Otwarto - jak pisał -5 poziomów, po jednym słowiańskim i „wikingowskim” oraz 3 germańskie. Wskazywał, że uczeni polscy zainteresowali się już tą sprawą, na co wskazuje wizyta prof. Z. Wojciechowskiego. Sugerował, czy nie byłoby wskazane, aby kolejni polscy badacze przybyli tu i zorientowali się w „metodach i pracy stosowanej”. Jak podkreślał, „odwiedziny takie miałby pod względem politycznym duże znaczenie, gdyż podkreślałby obiektywne ustosunkowanie naszej nauki do zagadnień z jednej strony, a z drugiej zapobiegły - - wykorzystywaniu wollińskich wykopalisk pod względem podkreślania rzekomej niskości kulturalnej Słowian, co miało miejsce przy znanych odkrywkach w Santoku". Poprosił też o instrukcję, czy ma nawiązać rozmowy o udziale polskich badaczy w wykopaliskach. Do swojego listu załączył też artykuł prasowy informujący o prowadzonych pracach ${ }^{19}$. Nie czekając na odpowiedź ministerstwa - w zasadzie równolegle, gdyż 25 września - konsul wysłał list do trzech profesorów: Włodzimierza Antoniewicza, Józefa Kostrzewskiego i Z. Wojciechowskiego, z analogicznym zapytaniem. Podkreślił duże znaczenie wizyty pod względem politycznym, gdyż pokazałaby obiektywne ustosunkowanie się polskiej nauki do niemieckich badań, a z drugiej zapobiegła wykorzystaniu wyników do umniejszania roli Słowian, jak to się stało w Santoku ${ }^{20}$.

W odpowiedzi Z. Wojciechowski podniósł, że wykopaliska wolińskie, o czym miał okazję sam się przekonać, mają pierwszorzędne znaczenie dla wczesnych dziejów Polski. O swoich spostrzeżeniach napisał w dwóch artykułach w Rocznikach Historycznych i Tęczy. Wskazywał, że taki wyjazd jest konieczny, i sugerował, że wziąć powinni w nim wziąć udział profesorowie W. Antoniewicz, Józef Kostrzewski i Leon Kozłowski, ówczesny prezes Rady Ministrów, który jednak zapewne nie znajdzie na to czasu, ale niewątpliwie poprze tę inicjatywę; poinformował już zresztą premiera o sprawie podczas międzynarodowego Zjazdu Slawistów w Warszawie, który odbył się we wrześniu 1934 r. Jako kolejne nazwiska osób zainteresowanych wskazał docentów Józefa Żurowskiego z Krakowa i Józefa Widajewicza z Poznania, sam też

18 Otto Kunkel (1895-1984), archeolog, od 1922 pracownik Muzeum Miejskiego w Szczecinie, w 1. 1927-1945 dyrektor Pomorskiego Muzeum Krajowego w Szczecinie, a w 1. 19531960 dyrektor Muzeum Prahistorycznego w Monachium (M. S z u k a ła, Martin Wehrmann i Otto Kunkel - ich rola w nauce i kulturze Szczecina końca XIX i pierwszej połowy XX wieku, w: Muzealnicy, archiwiści i bibliotekarze szczecińscy w XX wieku, Szczecin 2002, s. 34-38; W. S tę p iń s k i, Czasopiśmiennictwo historyczne Pomorza Zachodniego od drugiej połowy XX wieku po czasy współczesne, Zapiski Historyczne 63, 1998, z. 2, s. 55; por. K. T. I n a c h i n, Pommern als Grenzprovinz in der Agitation der politischen Rechten 19191933, w: Pogranicze polsko-niemieckie. Przeszłość - teraźniejszość - przyszłość, Szczecin 2001, s. 129-163).

19 Warszawa, Archiwum Akt Nowych (dalej cyt.: AAN), Konsulat w Szczecinie (dalej cyt.: KS), sygn. 45, s. 4. We wszystkich cytatach zachowano oryginalną pisownię.

${ }^{20}$ AAN, KS, sygn. 45, s. 3. 
wyraził chęć wzięcia udziału w eskapadzie ${ }^{21}$. Podobnie W. Antoniewicz podkreślił rolę badań w Wolinie („niezmiernej wartości”). Dodawał, że choć z materiałów wynika, iż prowadzone są przez uczonych niemieckich „doskonale”, niemniej jednak „nader korzystne” dla strony polskiej byłoby zobaczenie prac $\mathrm{w}$ terenie, podobnie też w Santoku. Sam wyraził chęć poznania tych stanowisk, jednakże z powodu zaawansowanej jesieni i krótkich dni wyjazd byłby trudny. Wiedział od prof. Wilhelma Unverzagta, że w Santoku zakończono już tegoroczne prace, więc zapewne zakończono je i w Wolinie. Dlatego też zasugerował wyprawę w maju ${ }^{22}$. W zbliżonym tonie odpowiedział również J. Kostrzewski, który napisał, że z uwagi na obowiązki nie może wyjechać w tym roku, ale w kolejnym chciałby obejrzeć wykopaliska wolińskie, tak jak zobaczył już te w Santoku, oraz porównać je z Biskupinem, do którego chce zaprosić W. Unverzagta ${ }^{23}$.

Odpowiedź Ministerstwa Spraw Zagranicznych na pismo Sztarka wysłano dopiero 21 XII 1934 r. Zastępca Naczelnika Wydziału Prasowego, Aleksy Wdziękoński, informował w nim, że sprawa wyjazdu została omówiona z dziekanem Wydziału Humanistycznego Uniwersytetu Warszawskiego, prof. W. Antoniewiczem, a także z Ministerstwem Wyznań Religijnych i Oświecenia Publicznego. A. Wdziękoński sugerował, że pożądane jest uzyskanie zaproszenia od strony niemieckiej, a także wskazał nazwiska uczonych, którzy powinni nim być objęci: W. Antoniewicza, J. Żurowskiego i Tadeusza Sulimirskiego z Uniwersytetu Jana Kazimierza we Lwowie. Pisał też, że nie miałby nic przeciw zaproszeniu J. Kostrzewskiego, a jego wyjazd byłby nawet „zasadniczo pożądany, ale sugestie w tym względzie musiałby być poczynione oględnie, a to ze względu na być może zbyt dobrze znane w Niemczech antyniemieckie nastawienie prof. Kostrzewskiego"24.

Po odpowiedzi MSZ działania wokół planowanej wizyty nabrały tempa. Już 4 I 1935 r. referent handlowy konsulatu Teodor Szotek z polecenia konsula H. Sztarka odwiedził dyrektora Pomorskiego Muzeum Krajowego O. Kunkla ${ }^{25}$. Podczas rozmowy nawiązał do wizyty na Pomorzu Konrada Jażdżewskiego w 1931 r. i wskazał, że wyjazdem interesują się W. Antoniewicz, J. Kostrzewski, J. Widajewicz, Z. Wojciechowski i J. Żurawski, a najbardziej odpowiadałby im maj 1935 r. O. Kunkel wyraził zadowolenie z zainteresowania strony polskiej i zaoferował pomoc ${ }^{26}$. Zaproponował

${ }^{21}$ AAN, KS, sygn. 45, s. 5-6.

${ }^{22}$ AAN, KS, sygn. 45, s. 7-8.

${ }^{23}$ AAN, KS, sygn. 45, s. 13. W. Unverzagt przebywał w Biskupinie we wrześniu 1935 (ADAMNSz, teczka nr 1762, s. 89: list W. Unverzagta do O. Kunkla, 21 IX 1935) oraz ponownie w sierpniu 1937 r. (S. G r u n w a ld, „Die Aufteilung der Burgen auf die Geschichte wird eine Änderung erfahren müssen“. Zur Geschichte der Zantoch-Idee, Acta Praehistorica et Archaeologica 41, 2009, s. 255).

${ }^{24}$ AAN, KS, sygn. 45, s. 17-18.

25 Wizytówka T. Szotka zostawiona O. Kunklowi zachowała się w aktach odwiedzin w Muzeum, z adnotacją Kunkla, że wizyta nastąpiła 3 I 1935 r. (ADAMNSz, teczka nr 1949, s. 48).

${ }^{26}$ Warto tu zaznaczyć, że wraz z rozpoczęciem badań w Wolinie w kwietniu 1934 r. O. Kunkel rozesłał informacje o tym do czynników urzędowych, ale też i do uznanych niemieckich uczonych, m.in. Alberta Brackmanna, Adolfa Hofmeistera czy Carla Schuchhardta, oraz do prasy - m.in. Pommersche Zeitung (korespondencja zachowana w poszycie: ADAMNSz, teczka nr 1761). W liście do prof. Bolka von Richthofena pisał, że dostał zaproszenie na kongres 
też odwiedzenie innych stanowisk, dodając, że zaprosiłby do Szczecina różnych niemieckich prahistoryków, co stworzyłoby możliwość wymiany poglądów. W związku z tym potrzebowałby możliwie wczesnego uzgodnienia i ustalenia daty. Dodał też, że nie wiadomo, kiedy zaczną się prace w Wolinie, ze względu na brak środków. Jeśli takowe się znajdą, badania zostaną wznowione 1 kwietnia. Wskazał wreszcie, że niezależnie od tego, czy prace te ruszą, przyjazd polskich uczonych i zapoznanie się z wynikami z $1934 \mathrm{r}$. byłyby i tak pożądane ${ }^{27}$.

Następnego dnia H. Sztark wysłał list do premiera L. Kozłowskiego, w którym nawiązując do korespondencji z Z. Wojciechowskim, przesłał notatkę służbową urzędnika konsulatu T. Szotka z rozmowy z O. Kunklem oraz miesięcznik Das Bollwerk (nr 10 z listopada 1934 r.) z artykułem tegoż Kunkla o wykopaliskach. Podkreślił też, że przyjazd profesorów polskich jest bardzo wskazany ${ }^{28}$. Te same załączniki wysłał też tego samego dnia do W. Antoniewicza, Kostrzewskiego, Widajewicza, Wojciechowskiego i Żurawskiego wraz z informacją, że będzie zobowiązany za dalsze wiadomości, gdyż dr Kunkel pragnąłby możliwie wcześniej otrzymać szczegóły dotyczące wizyty ${ }^{29}$.

W drugiej połowie stycznia spłynęły odpowiedzi od poznańskich uczonych, którzy poinformowali konsula, że skierowali do Ministerstwa Wyznań Religijnych i Oświecenia Publicznego prośbę o przyznanie zasiłku na wyjazd. J. Kostrzewski dodał, że woli przyjechać, gdy znaczniejsza część terenu będzie rozkopana i będzie można lepiej się zapoznać z wynikami. Jeśli prace zaczną się 1 kwietnia, to w połowie maja powinno być widać konstrukcje. Jak wynika z listu Z. Wojciechowskiego, organizacji wyjazdu podjął się J. Kostrzewski ${ }^{30}$. Z kolei T. Sulimierski 12 lutego powiadomił Sztarka, że termin wyjazdu jest dla niego obojętny, ale nie dysponuje ani funduszami, ani paszportem, zatem nie widzi możliwości uczestnictwa w wyprawie ${ }^{31}$. O rozmowach i korespondencji z polskimi uczonymi i O. Kunklem konsul H. Sztark informował MSZ w lutym $1935 \mathrm{r}^{32}$

O. Kunkel 4 lutego zawiadomił polski konsulat o otwarciu w muzeum w Szczecinie wystawy czasowej ukazującej wyniki badań wolińskich ${ }^{33}$. Informację tę H. Sztark 11 lutego rozesłał do Antoniewicza, Kostrzewskiego, Sulimirskiego, Widajewicza,

slawistów do Warszawy, ale ze względów czasowych odmówił wzięcia udziału. Dodał jednak, że jeśli ze względu na niemiecki interes wskazane byłoby ukazanie tematu badań w Wolinie (w formie sprawozdania ze zdjęciami) i uzyska zwrot kosztów podróży, to pozostaje do dyspozycji (ADAMNSz, teczka nr 1761, s. 17).

${ }^{27}$ AAN, KS, sygn. 45, s. 11-12 (notatka służbowa T. Szotka z rozmowy z O. Kunklem).

${ }^{28}$ AAN, KS, sygn. 45, s. 9.

${ }^{29}$ AAN, KS, sygn. 45, s. 10. Niespełna miesiąc później (1 II 1935) taką samą korespondencję wysłał H. Sztark wszystkim tu wymienionym uczonym oraz prof. T. Sulimierskiemu (AAN, KS, sygn. 45, s. 19).

${ }^{30}$ AAN, KS, sygn. 45, s. 15, s. 21, s. 23. Z. Wojciechowski donosił też konsulowi, że w Szczecinie sprawom polskim poświęcił uwagę dyrektor archiwum, dr Erich Randt, który w Baltische Studien za rok 1934 dokonał przeglądu poloników z nastawieniem - jak się wyraził narodowo-niemieckim, złagodzonym przez obecne stosunki polsko-niemieckie. Por. P. M i gd a 1 s k i, Słowiańszczyzna północno-zachodnia, s. 254.

${ }^{31}$ AAN, KS, sygn. 45, s. 26.

${ }^{32}$ AAN, KS, sygn. 45, s. 16.

${ }^{33}$ AAN, KS, sygn. 45, s. 25. 
Wojciechowskiego i Żurawskiego ${ }^{34}$. Zachowana jest odpowiedź W. Antoniewicza z 21 lutego, w której informuje on, że nie może teraz przyjechać do Szczecina, ale zapewnia, że będzie się starał przybyć w maju wraz z kolegami ${ }^{35}$.

Zainteresowanie polskich (zwłaszcza poznańskich) badaczy Wolinem zaowocowało również działaniami popularyzatorskimi. Prowadzący szeroką aktywność publicystyczną J. Kostrzewski w marcu 1935 r. ogłosił na łamach Kuriera Poznańskiego tekst o Wolinie ${ }^{36}$, Z. Wojciechowski zaś w ramach Wszechnicy Uniwersytetu Poznańskiego wygłosił w marcu 1935 r. wykład pt. Gdzie Odra trzema ramionami ku morzu sięga, o czym donosił także Kurier Poznański ${ }^{37}$. Działania te były obserwowane przez stronę niemiecką. Regierungspräsident z Kwidzynia (ówcześnie Marienwerder) dr Karl Budding ${ }^{38}$ poinformował 7 III 1935 r. O. Kunkla, że w materiałach Publikationsstelle des Preußischen Geheimen Staatsarchivs znalazł informację o wspomnianym artykule J. Kostrzewskiego z Kuriera Poznańskiego ${ }^{39}$. Według Buddinga, Kostrzewski napisał, że Wolin to dawne słowiańskie miasto, poprzednik dzisiejszej Gdyni i dalsze badania wykopaliskowe prowadzone będą przy częściowym udziale polskich uczonych ${ }^{40}$. Kunkel w swojej odpowiedzi, zachowującej zresztą dość asekuracyjny w świetle dotychczasowych negocjacji charakter, wskazał, że mniemanie Kostrzewskiego o udziale polskich uczonych jest przedwczesne. Dodał również, że na ustne zapytanie konsula o możliwość odwiedzin polskich uczonych odpowiedział także ustnie, iż otrzymają takie samo wsparcie, jak badacze niemieccy wizytujący Polskę. Wskazał wreszcie, że poprosił o pisemne zapytanie, aby mógł zwrócić się do swoich naukowych i politycznych zwierzchników, do tej pory jednak pismo takie nie wpłynęło ${ }^{41}$.

List Buddinga sprawił, że dyrektor szczecińskiego muzeum sam zwrócił się do Publikationsstelle o wspomniany materiał. Otrzymał go 12 marca od Hansa Bellée z polecenia szefa tej placówki, prof. Alberta Brackmanna ${ }^{42}$. Następnego dnia wysłał

${ }^{34}$ AAN, KS, sygn. 45, s. 24.

${ }^{35}$ AAN, KS, sygn. 45, s. 27.

${ }^{36}$ J. K o s t r z e w s k i, Słowiańska królowa Bałtyku wyjrzała z pod ziemi, Kurier Poznański, nr 101 (2 III 1935), s. 5.

37 „Wołyń” u ujścia Odry, Kurier Poznański, nr 151 (31 III 1935), s. 8; wycinek w: AAN, KS, sygn. 45, s. 28.

38 Warto tu może dodać, że dr K. Budding był aktywnym uczestnikiem i obserwatorem sporu historyków polskich i niemieckich, m.in. współautorem, obok Johannesa Papritza i Waltera Reckego, tajnego opracowania dotyczącego relacji polsko-niemieckich w dziejach, przygotowanego na Międzynarodowy Kongres Historyczny w Warszawie w 1933 r.; zob. M. S z u k a ła, Pruskie archiwa, s. 133; M. B u r l e i g h, Germany Turns Eastwards. A Study of Ostforschung in the Third Reich, Cambrigde 1988, s. 59-61.

${ }^{39} \mathrm{~W}$ przekładzie niemieckim tytuł artykułu brzmiał: Die slawische Koenigin der Ostsee hat der Erde hervorgeblickt.

${ }^{40}$ ADAMNSz, teczka nr 1762, s. 20.

${ }^{41}$ ADAMNSz, teczka nr 1762, s. 21.

42 ADAMNSz, teczka nr 1762, s. 24, s. 25 (Polnische Presseauszüge, nr 102, 5 III 1935). Na temat tego badacza zob. M. B u r le i g h, Albert Brackmann and the Nazi adjustment of history, History Today 3, 1987, s. 42-46; t e n ż e, Germany Turns Eastwards; K. Z e r n a c k, „Niemcy i Wschód” jako problem badań historycznych w Berlinie, w: tenże, Niemcy Polska. Z dziejów trudnego dialogu historiograficznego, tłum. Ł. Musiał, Poznań 2006, s. 145 n. 
do Publikationsstelle pismo, w którym tłumaczył się podobnie, jak wcześniej Buddingowi ${ }^{43}$. Kilka miesięcy później, 2 lipca, do O. Kunkla spłynął z Publikationstelle również artykuł z Dziennika Bydgoskiego (Die altslawische Stadt Vineta), przesłany przez samego Johannesa Papritza ${ }^{44}$.

W kolejnym zachowanym liście do Sztarka z 4 IV 1935 r. Kostrzewski zaproponował udział w wyjeździe także dyrektora Państwowego Muzeum Archeologicznego Romana Jakimowicza oraz informował, że nie otrzymał odpowiedzi z Ministerstwa Wyznań Religijnych i Oświecenia Publicznego na wniosek o zasiłki, dlatego też nie zaczęto jeszcze starań o ulgowe paszporty. Pytał, czy wykopaliska na pewno się odbędą $a^{45}$. W odpowiedzi Sztark pisał, że dotychczas nie ma informacji o uzyskaniu finansowania wykopalisk, a decyzja o tym ma zapaść w końcu miesiąca. Wskazywał też, że według O. Kunkla przyjazd jest opłacalny ze względu na możliwość zbadania wyników dotychczasowych eksploracji. Z uwagi na pewne przygotowania strony niemieckiej termin przyjazdu ustalony został na drugą połowę kwietnia ${ }^{46}$.

Konsul Sztark o wszystkich działaniach na bieżąco informował MSZ, wskazując w maju, że badanami wolińskimi interesują się Wojciechowski, Widajewicz, Jakimowicz oraz były już premier Kozłowski. Pytał, czy ma skierować zaproszenie także do tych uczonych ${ }^{47}$, na co Ministerstwo odpowiedziało 31 maja, że nie widzi przeszkód ${ }^{48}$.

Niestety w tym momencie korespondencja urywa się na ponad miesiąc. Dopiero 6 lipca J. Kostrzewski ponownie informował H. Sztarka, że dotąd nie otrzymał odpowiedzi na wniosek o zasiłek, co uniemożliwia mu wyjazd do Szczecina. Dodał zrezygnowany, że „może nadarzy się inna jaka okazja do obejrzenia ich po drodze, np. w roku przyszłym z okazji podróży na II międzynarodowy kongres prehistoryczny w Oslo". Nadmienił, że dalej bada osadę w Biskupinie, która jest „wyjątkowo ciekawa” i warto zaprosić tam prehistoryków niemieckich, np. O. Kunkla i W. Unverzagta. Na zakończenie zaprosił też samego Sztarka do odwiedzenia Biskupina ${ }^{49}$. Konsul Sztark musiał dowiedzieć się w tym czasie o terminie rozpoczęcia wykopalisk w Wolinie, gdyż 12 lipca rozesłał do Ministerstwa Wyznań Religijnych i Oświecenia Publicznego oraz do Antoniewicza, Kostrzewskiego, Sulimirskiego, Widajewicza, Wojciechowskiego, Żurowskiego i Jakimowicza informację, że wznowienie eksploracji w Wolinie nastąpi 1 sierpnia, a sezon ten będzie być może ostatni ${ }^{50}$. Wkrótce zapytał też O. Kunkla o termin rozpoczęcia badań w Wolinie. Ten odpowiedział mu pisemnie 25 lipca, że druga część badań zacznie się 12 sierpnia i potrwa do końca października. Celem ich ma być - wskazywał - głównie topograficzne rozpoznania w miejscach, gdzie nie oczekuje się tak spektakularnych resztek drewnianych, jak w ubiegłym roku. Odwiedziny najlepiej będzie zorganizować między połową września a połową października. Powinno się je powiązać z odwiedzinami szcze-

${ }^{43}$ ADAMNSz, teczka nr 1762, s. 26.

${ }^{44}$ ADAMNSz, teczka nr 1762, s. 51 i 52 (Polnische Presseauszüge, nr 219, 21 VI 1935).

${ }^{45}$ AAN, KS, sygn. 45 , s. 30.

${ }^{46}$ AAN, KS, sygn. 45, s. 29.

47 AAN, KS, sygn. 45, s. 31 (list H. Sztarka do MSZ, 11 IV 1935).

${ }^{48}$ AAN, KS, sygn. 45, s. 32.

${ }^{49}$ AAN, KS, sygn. 45, s. 33.

${ }^{50}$ AAN, KS, sygn. 45, s. 34. 
cińskiego muzeum, gdzie znajdują się znaleziska z poprzedniego roku. Prosił też o możliwie wczesne poinformowanie ${ }^{51}$. W podziękowaniu z 29 lipca konsul wskazał, że posyła te informacje dalej do Polski, oraz dodał, że badacze polscy prawdopodobnie przyjadą do Niemiec ${ }^{52}$.

Konsul H. Sztark w dalszym ciągu starał się na bieżąco informować polskich badaczy o niemieckich działaniach na polu prehistorii: 30 VII 1935 r. wysłał im informację, że w miesięczniku Unser Pommerland ukazał się artykuł Hansa Jürgena Eggersa i Hermanna Bollnowa o prehistorii ziemi bobolickiej ${ }^{53}$, natomiast 5 września przekazał artykuły Kunkla ze Stettiner General-Anzeiger pt. Tatsachen über Wollin - Mitteilungen der Grabungsleiter ${ }^{54}$. Zostały one następnie przetłumaczone i opublikowane przez Z. Wojciechowskiego na łamach Roczników Historycznych ${ }^{55}$. Razem z nimi ukazał się też krótki artykuł K. Tymienieckiego polemizującego z niektórymi tezami O. Kunkla. Swoje „uwagi, a raczej nawet przypomnienia zamieścił” - podkreślał polski autor - w imię dążenia do „odkrywania prawdy i samej tylko prawdy" ${ }^{\prime 56}$. Teksty te ukazały się jednak drukiem już po wyprawie. Należy tu podkreślić, że z zachowanych akt konsulatu wynika, że H. Sztark dostawał w tym okresie na bieżąco sprawozdania z badań od O. Kunkla.

Z. Wojciechowski 19 X 1935 r. poinformował konsula, że po długich staraniach w końcu miesiąca dojdzie do skutku wyjazd pięciu profesorów Uniwersytetu Poznańskiego do Wolina. W związku z tym zapytał, kiedy jest ostateczny termin przyjazdu - tj. kiedy wykopaliska zostaną zasypane. Gościom najbardziej pasowałyby pierwsze dni listopada ${ }^{57}$. W odpowiedzi z 21 października H. Sztark pisał, że według informacji otrzymanej od O. Kunkla nie ma ustalonego terminu zasypania wykopów. Jednak deszczowa pogoda oraz piaskowy grunt sprawiły, że niektóre już zostały zasypane, inne zaś uda się utrzymać do początku listopada - w tej sprawie Kunkel porozumie się jeszcze z kierownikiem robót. Dyrektor muzeum informował, że istnieje też możliwość obejrzenia wydobytych przedmiotów w Szczecinie i w Wolinie oraz zbiorów zdjęć. Sztark przesłał też sprawozdanie z badań za okres od 12 września do 12 października oraz poprosił o możliwe szybkie podanie dokładnego terminu i czasu przyjazdu, będzie zaś oczekiwać na profesorów 3-4 listopada ${ }^{58}$.

${ }^{51}$ ADAMNSz, teczka nr 1761, s. 70; toż: AAN, KS, sygn. 45, s. 36 (odpis), 40. Pismo to wraz z artykułem o wznowieniu badań z Stettiner General-Anzeiger (nr 205 z 27 VII 1935) H. Sztark 27 VII 1935 r. przesłał W. Antoniewiczowi, J. Kostrzewskiemu, T. Sulimirskiemu, J. Widajewiczowi, J. Żurawskiemu, R. Jakimowiczowi (AAN, KS, sygn. 45, s. 35).

${ }_{52}$ ADAMNSz, teczka nr 1761, s. 71.

53 AAN, KS, sygn. 45, s. 43.

${ }^{54}$ AAN, KS, sygn. 45, s. 56. Zob. też Źródła do kaszubsko-polskich aspektów, t. IV, nr 43, s. 99-104. W AAN, KS, sygn. 45, s. 44-55, zachowany jest oryginalny maszynopis tego artykułu, dłuższy od tego zamieszczonego w prasie.

${ }_{55}$ Z. Woj c i e chows ki, Jeszcze słowo o Wolinie, Roczniki Historyczne 11, 1935 , s. 211-217.

${ }^{56}$ K. Ty mi e n i e c k i, W sprawie Wolina, Roczniki Historyczne 11, 1935, s. 217-221.

57 AAN, KS, sygn. 45, s. 63.

58 AAN, KS, sygn. 45, s. 64. W tym samym dniu H. Sztark wysłał też list do J. Widajewicza, w którym m.in. podziękował za otrzymane teksty o ujściu Odry (J. Wi d a j e w i c z, Położenie Jomsborga, Kwartalnik Historyczny 48, 1934; t e n ż e, Przy ujściu Odry w drugiej 
Zielone światło dane polskiej ekspedycji spowodowało konkretniejsze działania strony niemieckiej. 22 października O. Kunkel informował urząd nadprezydenta prowincji i gauleitera Pomorza Franza Schwede-Coburga o przyjeździe polskich badaczy na początku listopada 1935 r. do szczecińskiego muzeum i do Wolina. Pisał, że wizyta ta opiera się na wzajemności, na podstawie której niemieccy badacze znajdą możliwość odwiedzenia wykopalisk w Polsce. Meldował, że z powodu nagłego terminu zwraca się poza trybem urzędowym. Prosił o przydzielenie do zwiedzania przedstawiciela urzędu, który będzie ułatwiał - jak się wyraził - załatwienie kwestii nierozwiązanych (dodawał, że ta rozmowa powinna się odbyć w szczecińskim muzeum). Urzędnik ów powinien zdawać sobie sprawę z wagi wizyty. Wskazywał też, że konsul polski planuje do Wolina wybrać się autem, gdyż połączenie kolejowe nie jest korzystne, i zapytywał, czy ma wobec tego udostępnić mu samochód służbowy ${ }^{59}$.

Ostatecznie 23 października Z. Wojciechowski poinformował H. Sztarka, że grupa (profesorowie J. Kostrzewski, K. Tymieniecki i Z. Wojciechowski, docenci L. Koczy i J. Widajewicz) przyjedzie już w niedzielę 27 października o godz. 22 z minutami. Pierwszy dzień wizyty (28 października) przypadnie na Szczecin, następny zaś na Wolin ${ }^{60}$.

Przebieg wizyty poznajemy z dwóch sprawozdań, polskiego i niemieckiego. Polską relację H. Sztark wysłał 26 XI 1935 r. do ambasady w Berlinie i do MSZ. Zanotował w niej, że 28 października podejmował profesorów polskich śniadaniem, na które zaprosił również dyrektora muzeum O. Kunkla i delegata nadprezydenta prowincji pomorskiej oraz partii (NSDAP). Następnie uczeni zwiedzili muzeum, oprowadzani przez dyrektora. J. Kostrzewski przedstawił tam też stan prac wykopaliskowych w Biskupinie. Drugiego dnia zwiedzono miejsca wykopalisk w Wolinie oraz obejrzano wydobyte przedmioty. Według uczonych polskich odkopywane miasto (Vineta), jest pochodzenia słowiańskiego, co już nawet zaczynają przyznawać uczeni niemieccy (Dr. Kunkel), zastrzegając się, że ostateczne wnioski będzie można wyciągnąc dopiero po dłuższym okresie czasu". Jest to o tyle ważne, dodawał, że wysuwano wcześniej tu tezę, jakoby Słowianie byli elementem napływowym i zakładali swe osady tam, gdzie wcześniej istniało osadnictwo germańskie. Informował też, że polscy uczeni zamierzają przybyć do Szczecina również w roku następnym, aby poznać wyniki wykopalisk, ale też topografię terenów związanych z dziejami Polski. Na koniec wskazał, że przyjazdy polskich uczonych i zetknięcie się z niemieckimi kolegami powodują, że ci ostatni - nastawieni na osiąganie celów politycznych - zostają przyhamowani, Polakom zaś pozwala to na wysunięcie „,własnych poglądów i tez”61.

Znacznie bardziej szczegółowe jest sprawozdanie O. Kunkla napisane już 2 XI 1935 r. dla urzędu nadprezydenta ${ }^{62}$. Pisał on, że 28 października w godzinach 10-12

połowie X wieku, Poznań 1935) - AAN, KS, sygn. 45, s. 65.

${ }^{59}$ ADAMNSz, teczka nr 1949, s. 66.

${ }^{60}$ AAN, KS, sygn. 45 , s. 66.

${ }^{61}$ AAN, KS, sygn. 45, s. 69-70.

${ }^{62}$ Po wizycie polskich profesorów urząd nadprezydenta prowincji już 29 X 1935 r. wysłał pismo do O. Kunkla, że oczekuje pisemnego sprawozdania z wizyty, ten zaś wysłał list do H. Sztarka z prośbą o spis gości; H. Sztark odpowiedział mu już 30 października - ADAMNSz, teczka nr 1949, s. 68 , s. 67. 
pod jego kierunkiem, a w obecności wyższego radcy rządowego Dielitza i okręgowego opiekuna kulturalnego (Gaukulturwart) Johannesa Diebenowa ${ }^{63}$, konsula Sztarka i sekretarza konsulatu, polscy uczeni zwiedzili muzeum. Wszyscy następnie wzięli udział w obiedzie w polskim konsulacie (godz. 14-16) ${ }^{64}$, gdzie po pożegnaniu z niemieckimi uczestnikami goście polscy pozostali. Trzech z nich pojechało tego samego wieczora do Wolina, pozostali wraz z O. Kunklem przybyli we wtorek z konsulem jego samochodem. W Wolinie zwiedzili wykopaliska i wystawę oraz zapoznali się z ogólną topografią miasta. Wczesnym południem rozpoczęli pociągiem lub samochodem podróż powrotną. To, co zobaczyli poznańscy uczeni, uczyniło na nich, pisał Kunkel, wielkie i mylne wrażenie, że Pomorskie Muzeum Krajowe jest wspierane przez państwo, ale zostali oczywiście właściwie poinformowani. Dyrektor, po konsultacji z Dielitzem i J. Diebenowem, wyjaśnił też sytuację regionu pogranicza (Marchii Granicznej), ponieważ dwóch poznańskich gości chciało na tym terenie zobaczyć „niepraktykowane w Polsce zjawisko (które winno się nazywać »polityzowaniem« muzeum archeologicznego i nauki)". O. Kunkel odpowiedział na tę sugestię, że z niemieckiego punktu widzenia nie chodzi tu o żadną naukę czy o starożytnictwo, ale o edukację ludności zamieszkującej ten rzadko zasiedlony obszar. Działania te mają sprawić, żeby mieszkająca tu społeczność poczuła się bardziej u siebie oraz lepiej zrozumiała to miejsce i jego potrzeby na niemieckim wschodzie. Z wyjaśnieniami O. Kunkla, jak podkreślono w sprawozdaniu, dwaj polscy profesorowie, w tym Kostrzewski, mieli się w pełni zgodzić 65 .

Jak wynika z zachowanych dokumentów, co zgadza się też ze sprawozdaniem O. Kunkla, podczas podróży powrotnej J. Kostrzewski miał razem z J. Widajewiczem $^{66}$ odwiedzić Piłę (stolicę Marchii Granicznej) i tamtejsze muzeum ${ }^{67}$, mieszące się wówczas w monumentalnym gmachu Reichsdankhausu (Dom Wdzięczności Rzeszy). J. Widajewicz jednak „odmyślił się po drodze” i dlatego J. Kostrzewski pojechał tam sam. Kostrzewski określił muzeum w Pile jako „bardzo ciekawe i oczywiście tak samo przystosowane do celów politycznych jak muzeum szczecińskie"68. H. Sztark

${ }^{63}$ J. Diebenow wiedział już wcześniej o wykopaliskach w Wolinie. Został nawet zaproszony 8 VIII 1935 r. przez O. Kunkla do odwiedzenia Wolina (ADAMNSz, teczka nr 1761, s. 76).

${ }^{64}$ Konsul wraz z żoną Anielą Sztark zaprosił też Kunkla z okazji wizyty profesorów na obiad w dniu 28 października o godz. 14.00 (ADAMNSz, teczka nr 1949, s. 66, wpłynęło do muzeum 27 X 1935).

${ }^{65}$ ADAMNSz, teczka nr 1949, s. 69-70.

${ }^{66}$ Według K. S m o g o r z e w s k i e g o, Spojrzenie w zaranie Państwa Polskiego, Gazeta Polska nr 356 (24 XII 1935), s. 13, K. Tymieniecki, L. Koczy i Z. Wojciechowski mieli wrócić do Poznania przez Berlin.

${ }^{67} \mathrm{Na}$ temat historii Muzeum Krajowego w Pile dla Prowincji Marchia Graniczna Poznań - Prusy Zachodnie oraz roli archeologii w tej placówce zob. A. K o k o w s k i, Kreismuseum Flatow (Złotów) - Provinzmuseum Schneidemühl (Piła). Nieznane dzieje archeologicznych zbiorów muzealnych w dawnej prowincji Grenzmark Posen-Westpreussen, Fontes Archaeologici Posnanienses 47, 2011, s. 350-360; t e n ż e, Robert Liebig. Archeolog amator z Wielkopolski / Einer Amateurarchäologe aus Großpolen, Lublin 2016, s. 126-130.

${ }^{68}$ Warto tu dodać, że polityczne znaczenie muzeum w Pile podkreślano otwarcie $\mathrm{w}$ tym czasie, m.in. w materiałach prasowych o odbywającym się 17-18 X 1935 r. kongresie prehistorycznym w Pile (A. K o k ow s ki, W. N i e m i r o w s k i, Na tropie zaginionych odkryć. Archeologia w świetle doniesień prasowych z dawnej prowincji Grenzmark Posen-Westpreußen 
polecił opiekę nad J. Kostrzewskim polskiemu konsulowi z Piły, dr. Tadeuszowi Drobniakowi ${ }^{69}$. O podtrzymaniu nawiązanych kontaktów świadczy też zachowany list T. Drobniaka do J. Kostrzewskiego z 20 III 1937 r., w którym konsul przesłał kolejne wycinki prasowe na temat prehistorii oraz odpis z wykładu o archeologii niemieckiej na pograniczu, który odbył się 15 III $1937 \mathrm{r}^{70}$

Dyrektor O. Kunkel zamieścił informację o wizycie polskich badaczy w oficjalnym sprawozdaniu z badań za okres od 12 października do 20 grudnia 1935 r. ${ }^{71}$ Przez jakiś czas starał się podtrzymać poprawne oficjalne stosunki z polskimi badaczami. Już 5 XI 1935 r. wysłał - na prośbę J. Kostrzewskiego -8 zdjęć z wykopalisk wolińskich z 1934 r. z zapewnieniami o tym, że wyniki z tegorocznych badań na Srebrnym Wzgórzu będą także dostępne dla strony polskiej ${ }^{72}$. Podobnie 6 VIII 1936 r. wysłał J. Kostrzewskiemu, W. Antoniewiczowi oraz Instytutowi Bałtyckiemu w Toruniu egzemplarz czasopisma Das Bollwerk ${ }^{73}$ z maja 1936 r., w którym publikowane było sprawozdanie z badań wolińskich. W dalszym ciągu przekazywał polskiemu konsulowi oficjalne sprawozdania $\mathrm{z}$ badań, które ten przesyłał następnie dalej polskim uczonym ${ }^{74}$.

Po powrocie z wyprawy ukazało się na łamach Roczników Historycznych sprawozdanie z wyjazdu pióra K. Tymienieckiego. Skupił się on jednak na omówieniu topografii Wolina oraz jego dziejach ${ }^{75}$. Jak wynika z listu J. Kostrzewskiego do H. Sztarka, badacze mieli też 6 listopada zreferować wyniki z podróży w (Polskim?) Towarzystwie Historycznym w Poznaniu, a Kostrzewski zamierzał też napisać coś

/ Auf den Spuren von verlorenen Entdeckungen die Archäologie im Spiegel der Presse der Ehemaligen Provinz Grenzmark Posen-Westpreußen, Lublin 2016, s. 485 n.).

${ }^{69}$ AAN, KS, sygn. 45, s. 71. Polską placówkę konsularną w Pile powołano w 1922 , a w 1928 r. podniesiono ją do rangi konsulatu (R. C h w a li s z ew s k i, Z działalności konsulatu Rzeczpospolitej Polskiej w Pile w latach 1922-1939, Piła 1984; H. Ch ału p c zak, Powstanie i działalność polskich placówek konsularnych w okresie międzywojennym (ze szczególnym uwzględnieniem pogranicza polsko-niemiecko-czechosłowackiego), w: Konsulaty na pograniczu polsko-niemieckim i polsko-czechosłowackim w latach 1918-1939, Katowice 2004, s. 19). O T. Drobniaku zob. R. C h w a l i s z e w s k i, Kierownicy konsulatu Rzeczypospolitej Polskiej w Pile w latach 1922-1939, Rocznik Nadnotecki 15-16, 1984-1985, s. 47-48. W szczątkowo zachowanych aktach konsulatu RP w Pile przechowywanych w AAN nie zachowały się niestety materiały dotyczące tej wizyty.

${ }^{70}$ Polska Akademia Nauk, Archiwum w Warszawie, Oddział w Poznaniu, Materiały Józefa Kostrzewskiego, brak sygnatury (zespół w trakcie opracowania, cyt. $<$ http://www.wbc.poznan. $\mathrm{pl} /$ dlibra/doccontent?id=322105>.

${ }^{71}$ AAN, KS, sygn. 45, s. 75-86, Ausgrabungen Wollin 1935. Dritter Zwischenbericht der Grabungsleitung (12. Oktober bis 20. Dezember); toż w: ADAMNSz, teczka nr 1760 (bez paginacji). Zachowana jest odpowiedź L. Koczego z 11 II 1936 r. z podziękowaniem i adnotacją, że wykorzysta informacje w pracy: The Baltic Country (AAN, KS, sygn. 45, s. 90).

72 ADAMNSz, teczka nr 1949, s. 72.

${ }^{73} \mathrm{O}$ czasopiśmie tym W. K e s s l e r, Zum Bild Pommerns in der nationalsozialistischen Publizistik. Einige Bemerkungen am Beispiel der Zeitschrift „Das Bollwerk”, w: Państwo i społeczeństwo na Pomorzu Zachodnim do 1945 r., Szczecin 1997, s. 337-348; W. S tę p i ń s k i, Czasopiśmiennictwo, s. 53.

${ }^{74}$ AAN, KS, sygn. 45, s. 87-89, s. 92, s. 93-99.

${ }^{75}$ K. Ty m i e n i e c k i, Sprawozdanie z ekspedycji naukowej do Wolina w dniach 28 i 29 października 1935, Roczniki Historyczne 11, 1935, s. 221-228. 
w prasie o podporządkowaniu archeologii celom politycznym ${ }^{76}$. Ukazały się również artykuły prasowe informujące o wizycie. Akredytowany w Berlinie dziennikarz Gazety Polskiej Kazimierz Smogorzewski zanotował, że normalizacja w stosunkach polsko-niemieckich przynosi owoce dla nauki, chwalił też uprzejmość O. Kunkla ${ }^{77}$. Artykuł ten, jak wskazuje Maciej Szukała, został przetłumaczony przez Publikationsstelle na język niemiecki i przekazany władzom archiwalnym. Temat wyprawy polskich profesorów na Pomorze podjęły także inne tytuły prasowe - Robotnik, Kurier Lwowski, Kurier Warszawski, Kurier Codzienny, Kurier Poznański ${ }^{78}$.

Jeszcze przed końcem roku, gdyż 20 XII 1935 r., H. Sztark wysłał serię listów do uczestników podróży. Leonowi Koczemu podziękował za publikacje ${ }^{79}$, które od niego otrzymał ${ }^{80}$. Konsul dostał też od Z. Wojciechowskiego zeszyt Roczników Historycznych, w którym ukazało się sprawozdanie K. Tymienieckiego z wyprawy, przy czym zwrócił uwagę, że należałoby również przesłać egzemplarz O. Kunklowi ${ }^{81}$.

Wyprawę polskich badaczy do Wolina należy traktować jako epizod nie tylko w historii polskiej i pomorskiej archeologii, ale przede wszystkim w dziejach polsko-niemieckich stosunków naukowych. Mimo że nie spełniła ona pokładanych w niej przez Z. Wojciechowskiego i H. Sztarka nadziei (a może też nie miała lub, co bardziej prawdopodobne, nie mogła spełnić), jest ona interesującym przykładem dwustronnych relacji i procesu organizacji wizyty naukowej na pograniczu dwóch państw, do niedawna wrogo do siebie nastawionych, a od deklaracji polsko-niemieckiej o niestosowaniu przemocy z 26 I 1934 r. pozostających w oficjalnie poprawnych relacjach.

Prześledzenie na podstawie zachowanych materiałów aktowych przygotowań oraz przebiegu wizyty ukazuje nie tylko wzajemną kurtuazję, delikatność zabiegów i podporządkowanie spraw nauki czynnikom politycznym, ale też związane z tym problemy organizacyjne ${ }^{82}$ i przede wszystkim finansowe nauki polskiej. Podobne problemy były zresztą i po stronie niemieckiej, o czym świadczą nie tylko opóźnienie wznowienia wykopalisk w 1935 r., ale też zanotowane przez Józefa Kisielewskiego utyskiwania jednego z badaczy Wolina - F. W. Sassego ${ }^{83}$. Jak można zaobserwować, wykorzystanie wolińskich badań archeologicznych w polityce historycznej III Rzeszy - to one stały się m.in. podstawą do wydania przez szefa Publikationsstelle Johannesa Papritza oraz Wilhelma Koppego w 1937 r. pierwszego numeru czasopisma Joms-

${ }^{76}$ AAN, KS, sygn. 45, s. 71. Zob. J. K o s tr z e w s k i, Zagadka Winety rozwiązana. Co znaleziono pod brukiem rynku w Wolinie, Ilustracja Polska 1936, nr 45, s. 1070.

${ }^{77}$ K. S m o g or z e w s k i, Spojrzenie w zaranie, s. 13.

${ }_{78}$ M. S z u k ała, Pruskie archiwa, s. 150-151, przyp. 583.

79 Chodziło o prace L. K o c z e g o: Jomsborg, Kwartalnik Historyczny 46, 1932, z. 3-4; Polska i Skandynawia za pierwszych Piastów, Poznań 1934; Związki małżeńskie Piastów ze Skandynawami, Slavia Occidentalis 11, 1932; Źródła staronordyckie do dziejów Słowian, Slavia Occidentalis 11, 1932.

${ }^{80}$ AAN, KS, sygn. 45, s. 72, s. 73.

${ }^{81}$ AAN, KS, sygn. 45, s. 74.

${ }^{82}$ Na uznanie zasługuje szybkość działania ówczesnej poczty w międzynarodowej wymianie korespondencji między Szczecinem a Poznaniem i Warszawą.

${ }^{83}$ J. K i s i e lew ski, Ziemia, s. 271; wcześniej fragment ten opublikowano w Tęczy (W. Fili p ow iak, M. Gi erke, K. Kok or a, M. Kow alska, Zaginiona dokumentacja, s. 27). 
burg $^{84}$ - nie oznaczało zapewnienia im bezpiecznego finansowania ${ }^{85}$. Nie pomagała temu nawet szeroko zakrojona i przedsięwzięta przez O. Kunkla akcja organizowania wizyt w Wolinie wielu uznanych badaczy z Niemiec i Europy ${ }^{86}$, a także liczne anonsy prasowe. Dodajmy, że zbliżoną akcję prowadził w tym samym czasie J. Kostrzewski wokół swoich wykopalisk w Biskupinie, który również odwiedzali liczni naukowcy, politycy, literaci, ludzie kultury ${ }^{87}$.

J. Kostrzewski po latach, wspominając wizytę w Wolinie, pisał, że „,chodziliśmy po tej starosłowiańskiej ziemi z dziwnymi uczuciami, oglądając wyniki rozkopywań niemieckich tego słynnego grodu portowego, znanego w legendach pod nazwą Winety. Nie przypuszczaliśmy wówczas, że dziesięć lat później wrócimy na tę ziemię już nie jako goście, lecz jako prawi jej właściciele" "88. Właściciele, którzy ostatecznie w 1952 r. podejmą własne dalsze badania archeologiczne w Wolinie ${ }^{89}$. Mówiono o nich już 1 III 1948 r. na konferencji w Naczelnej Dyrekcji Muzeów i Ochrony Zabytków, poświęconej przygotowaniom milenijnego planu badawczego. J. Kostrzewski powiedział wówczas: „Na Pomorzu - Rugia, Szczecin i Kołobrzeg, bez Wolina, którego nie potrzeba ruszać, bo po prostu nie mamy tyle ludzi, którzy mogliby te prace porządnie kontynuować, tak jak porządnie i systematycznie robili to Niemcy. Uważam, że kopanie Wolina tymi siłami, które mamy do dyspozycji, mogłoby po prostu doprowadzić do kompromitacji nauki polskiej”. K. Tymieniecki zaś wskazywał, że prace te są konieczne - „musimy wyświetlić to, co Niemcy przed nami świadomie zataili. Bo mamy relacje, że badania prowadzone przez Kunkla i Wildego doprowadziły do wyników rewelacyjnych dla samych Niemców, tak, że oni woleli tych badań nie kontynuować" ${ }^{9}$. Do prac w Wolinie przymierzał się w 1948 r. uczeń J. Kostrzewskiego, Tadeusz Wieczorowski, obecny zresztą razem

${ }^{84}$ J. P a pritz, W. Kop pe, Vorwort, Jomsburg 1, 1937, s. 1-2. Na temat tego czasopisma zob. m.in. M. B u r l e i g h, Germany Turns Eastwards, s. 136-146; J. H a c k m a n n, Deutsche Ostforschung und Geschichtswissenschaft, w: Deutsche Ostforschung und polnische Westforschung im Spannungsfeld von Wissenschaft und Politik. Disziplinen im Vergleich, t. I, Osnabrück-Poznań 2002, s. 33.

${ }^{85}$ Dokumentacja finansowa oraz korespondencja dotycząca tych badań zachowała się i czeka na dogłębną analizę.

${ }^{86}$ Pragnienie przyjazdu do Wolina zgłaszało wielu wybitnych prehistoryków, jak legenda meklemburskiej archeologii Robert Beltz (ADAMNSz, teczka nr 1761, s. 65). Przybywali tam także najważniejsi przedstawiciele ówczesnych niemieckich badań wschodnich, jak: Albert Brackmann, Johannes Papritz, Gerhard Sappok, Adolf Hofmeister (korespondencja dotycząca ich wizyt zachowana m.in. w: ADAMNSz, teczka nr 1761).

${ }^{87}$ D. P i o tr o w s k a, Biskupin - ideologie - kultura, w: Archeologia - kultura - ideologie, Biskupin-Wrocław 2004, s. 102-115.

88 J. K o s tr z e w s ki, Z mego życia, s. 205.

89 Szczerzej na temat polskich badań nad przeszłością Wolina zob. P. Migdalski, Między nauką, mitem a propagandą. Przeszłość Wolina w polskich badaniach oraz w życiu małego miasta na ziemiach zachodnich w okresie Polski Ludowej, Wodzisław Śląski 2019 (w przygotowaniu).

90 Warszawa, Archiwum Instytutu Archeologii i Etnologii PAN, Kierownictwo Badań nad Początkami Państwa Polskiego, sygn. KB/13, s. 12, 23 (stenogram z Konferencji w Naczelnej Dyrekcji Muzeów i Ochrony Zabytków w dniu 1 marca 1948 r. w sprawie prac, związanych z badaniem okresu powstania Państwa Polskiego). 
ze Zdzisławem Rajewskim w 1938 r. w Szczecinie i w Wolinie ${ }^{91}$.

Klimat wizyty z 1935 r. ukazuje, jak w nowych warunkach politycznych bardzo zmieniło się nastawienie niemieckich środowisk historycznych do polskich. Należy tutaj wskazać choćby problemy z uzyskaniem przez Konrada Jażdżewskiego dostępu do muzealiów pomorskich podczas wizyty w październiku $1931 \mathrm{r} \cdot{ }^{92} \mathrm{~W}$ tym czasie kłopoty z dopuszczeniem do materiałów archiwalnych w Niemczech mieli też historycy: Ludwik Papée w Królewcu w $1931^{93}$ czy Karol Górski także w Królewcu w 1932 r. ${ }^{94}$ Nagłośniony w polskiej prasie przypadek L. Papéego doprowadził do retorsji polskiej służby archiwalnej, co z kolei doprowadziło do tak zwanej wojny archiwalnej polsko-niemieckiej. To pogorszenie stosunków, także na niwie naukowej, wynikało, co podkreślił Maciej Szukała, ze zmiany sytuacji międzynarodowej - narastającego kryzysu ekonomicznego ${ }^{95}$.

Należy tu jednak podkreślić, zwłaszcza w kontekście wizyty w Wolinie, że już w pierwszym sezonie badawczym w końcu 1932 r. Kostrzewski odwiedził w porozumieniu z Unverzagtem badania archeologiczne w Santoku ${ }^{96}$. Niezależnie od tych drobnych uprzejmości w okresie tym niemieckie środowisko związane z badaniami wschodnimi przygotowało pod auspicjami A. Brackmanna na VII Międzynarodowy Kongres Historyczny w Warszawie (odbyty latem 1933 r.) publikację Deutschland und Polen ${ }^{97}$. Jej redaktorzy - Brackmann i Karl Brandi - uważali ją za próbę odpowiedzi na

${ }^{91}$ ADAMNSz, teczka nr 1949, s. 145 (pismo J. Kostrzewskiego do O. Kunkla, 25 XI 1938); por. K. K ow a ls ki, Wł. F i l i p ow i a k, Dawne zbiory archeologiczne Muzeum Narodowego w Szczecinie, w: Zaginione - ocalone. Szczecińska kolekcja starożytności pomorskich, Szczecin 2012, s. 9; Szczecin, Archiwum Państwowe, Muzeum Narodowe w Szczecinie, sygn. 3 (bez paginacji): Muzeum Pomorza Zachodniego w latach 1945-1965.

${ }_{92}$ K. J a ż d ż e w s k i, Pamiętniki. Wspomnienia polskiego archeologa z XX wieku, Łódź 1995, s. 77-79. Por. też K. K o w a ls ki, Kwerenda źródeł kultury pucharów lejkowatych przeprowadzona przez Konrada Jażdżewskiego w 1931 roku na obszarze ówczesnej prowincji Pomorze, Materiały Zachodniopomorskie, nowa seria 13, 2017, s. 9-34.

${ }^{3}$ C. B i e r n a t, Spór archiwalny polsko-gdańsko-niemiecki w okresie międzywojennym 1919-1939, Warszawa 1969, s. 154-155; M. S z u k a ł a, Pruskie archiwa, s. 100.

${ }^{94}$ K. G ó r s k i, Autobiografia naukowa, wyd. W. Sieradzan, Toruń 2003, s. 37-40. Por. Z. H. N o w a k, Starania Karola Górskiego o dostęp do archiwów Gdańska i Królewca w latach 1933-1938, w: Polska i jej sąsiedzi w czasach najnowszych. Studia i materiały ofiarowane profesorowi Karolowi Grünbergowi w 70-lecie urodzin, Torun 1995, s. 107-117; C. B i e r n a t, Spór, s. 151-163.

95 C. B i e r n a t, Spór, s. 154-155; M. S z u k ał a, Pruskie archiwa, s. 99-100. Warto tu zauważyć, że wcześniej w latach dwudziestych także mimo niekorzystnej atmosfery politycznej oraz stwarzania realnych problemów w udostępnianiu materiałów, niektórym badaczom polskim udało się przeprowadzić kwerendy w Niemczech. Byli to archeolodzy, między innymi Władysław Łęga w 1924 i Kostrzewski w 1927 r. w Szczecinie, a także historycy - J. Widajewicz w Berlinie czy Stanisław Bodniak w Gdańsku, Fromborku i Królewcu w 1929 r. - K. K o w a 1 s k i, Kwerenda, s. 14; J. L e ś n y, Józef Widajewicz, w: Wybitni historycy wielkopolscy, wyd. 2, Poznań 2010, s. 289; S. B o d n i a k, Życiorys własny, Pamiętnik Biblioteki Kórnickiej 5, 1955, s. 14-15; Z. K a l i s z, Stanisław Bodniak - historyk i bibliotekarz, Pamiętnik Biblioteki Kórnickiej 19, 1982, s. 172.

${ }_{96}$ S. Gru nw a 1 d, „Die Aufteilung der Burgen”, s. 255.

${ }^{97}$ Deutschland und Polen. Beiträge zu ihren geschichtlichen Beziehungen, red. A. Brackmann, München-Berlin 1933. 
fałszywe przedstawianie przez stronę polską i francuską problematyki historii stosunków polsko-niemieckich. Praca ta spotkała się z licznymi polemikami polskimi, publikowanymi m.in. na łamach Roczników Historycznych czy Kwartalnika Historycznego. Rozpowszechnianie książki było nawet w Polsce zakazane, na co zresztą Brackmann skarżył się Marcelemu Handelsmanowi. Należy tu dodać, że wydanie tej książki nakładało się na wzmożenie propagandy „korytarzowej” w Niemczech ${ }^{98}$.

Relacje polsko-niemieckie uległy zmianie po przejęciu władzy w Niemczech przez nazistów, którzy doprowadzili do podpisania polsko-niemieckiej deklaracji o niestosowaniu przemocy 26 I 1934 r. ${ }^{99}$ Jak wynika z dokumentów, obie strony uzgodniły zaprzestanie wzajemnych ataków publicznych. Zaczęto organizować integracyjne spotkania - pisarzy, naukowców, kombatantów, młodzieży oraz wojska. W III Rzeszy zlikwidowano nawet szereg organizacji ziomkowskich ${ }^{100}$. W nowych realiach ułatwiono naukowcom polskim przeprowadzenie kwerend w Niemczech ${ }^{101}$. W 1935 r. i ponownie jeszcze w 1939 r. odwiedził Gdańsk (podległy w pewnym sensie niemieckiej administracji archiwalnej) Karol Górski ${ }^{102}$. W 1936 r. Niemcy odwiedził Widajewicz ${ }^{103}$. Badacze polscy przyjeżdżali także na Pomorze Zachodnie - do Szczecina czy do Wolina. Wymienić tu należy Witolda Hensla (9-14 X 1937) ${ }^{104}$, ponownie Z. Wojciechowskiego (24 III 1938), Wandę Sommerfeld (24 VIII 1938) i jeszcze w marcu 1939 r. Stanisława Kota ${ }^{105}$. Z ocieplenia stosunków korzystali też naukowcy niemieccy. Po 1934 r. Polskę odwiedzili m.in. historycy Herbert Ludat (1935), Erich Maschke (lato 1934), Werner Conze (1937) ${ }^{106}$ i Gerhard Sappok (1934?) ${ }^{107}$. Zmiana stosunku do polskich naukowców nastąpiła w Niemczech w końcu 1938 r., a spowodowana była odrzuceniem przez Polskę niemieckich propozycji dotyczących

${ }_{98}$ M. M r o c z k o, Polska myśl zachodnia 1918-1939 (Kształtowanie i upowszechnienie), Poznań 1986, s. 284-286; B. P i o tr o w s k i, O Polskę, s. 274-280; M. B u r l e i g h, Germany Turns Eastwards, s. 59-70; M. S z u k a ła, Pruskie archiwa, s. 128-142.

${ }_{99}$ K. Pryt, Befohlene Freundschaft. Die deutsch-polnische Kulturbeziehungen 19341939, Osnabrück 2010.

${ }^{100}$ Szerszy kontekst polityczny dają M. B ro s z a t, 200 lat niemieckiej polityki wobec Polski, tłum. E. Kaczmarczyk, W. Leder, Warszawa 1999, s. 271 n.; M. W o j c i e c h o w s k i, Polsko-niemiecka deklaracja o nieagresji z 26 stycznia 1934 r., Katowice 1963, zwł. s. 32-39. Por. też M. B u r l e i g h, Germany Turns Eastwards, s. 64 n.; M. S z u k a ła, Pruskie archiwa, s. 128-142; 145-161; P. B i 1 i ń s k i, Władysław Konopczyński 1880-1952. Człowiek i dzieło, Kraków 2017, s. 348-351.

101 Warto jednak podkreślić, że - według badań M. S z u k a ły, Pruskie archiwa, s. 101 - w 1. 1934-1939 nadal 1/3 wniosków polskich badaczy o dostęp do archiwów niemieckich była odrzucana.

${ }^{102}$ K. G ó r s k i, Autobiografia, s. 45-54, 58.

103 J. L e ś n y, Józef Widajewicz, s. 289.

104 Warto może tu dodać, że w 1937 r. W. Unverzagt udostępnił W. Henslowi materiały fotograficzne z Santoka (S. G r u n w a ld, „Die Aufteilung der Burgen”, s. 255).

${ }_{105}$ ADAMNSz, teczka nr 1949, s. 105, 117, 140; M. S z u k a ł a, Pruskie archiwa, s. 108.

106 J. M. P i s k o r s k i, Herbert Ludat (1910-1993) - historyk Słowiańszczyzny Zachodniej i stosunków polsko-niemieckich, w: H. Ludat, Słowianie - Niemcy - Europa. Wybór prac, tłum. J. M. Piskorski, Marburg-Poznań 2000, s. 335-336; M. S z u k a ła, Pruskie archiwa, s. $106-110$.

${ }^{107}$ T. Z a d r o ż ny, Kajetan i inni (2). Oskarżające Gerharda pisanie, Cenne, Bezcenne, Utracone 2009, nr 4, s. 17-22. 
współpracy politycznej oraz budowy eksterytorialnej autostrady ${ }^{108}$. Sytuacja zaogniła się jeszcze bardziej w pierwszej połowie 1939 r., kiedy w kwietniu Adolf Hitler wypowiedział pakt z 26 I 1934 r. ${ }^{109}$ Skutki tych posunięć były widoczne podczas wspomnianej już wyżej wizyty T. Wieczorowskiego i Z. Rajewskiego na Pomorzu ${ }^{110}$. Wówczas to O. Kunkel zalecił K. Wildemu pokazać Polakom w Wolinie tyle tylko, ,ile jest możliwe i odpowiedzialne"111.

Analiza materiału z tego okresu pokazuje, że nie można zarzucać wszystkim naukowcom niemieckim wrogości względem polskich kolegów. Jak wynika z zachowanej korespondencji, publikowane przez Niemców sprawozdania i oficjalne dokumenty z wykopalisk wolińskich niekoniecznie odzwierciedlały ściśle poglądy pracujących przy nich badaczy, zwłaszcza Karla Wildego ${ }^{112}$, który w 1935 r. wykazywał zainteresowanie polskimi pracami (m.in. książką Kultura Pomorza autorstwa Władysława Łęgi) ${ }^{113}$. W kolejnym roku sam O. Kunkel chciał jechać do Biskupina, na co zgodę wyraziły nawet władze prowincji ${ }^{114}$. Potrzebę wyjazdu uzasadniał chęcią podtrzymania dobrych stosunków z przedstawicielami nauki polskiej ${ }^{115}$. Zaostrzanie się relacji polsko-niemieckich i ostatecznie wybuch II wojny światowej przekreśliły wkrótce te starania.

\section{BIBLIOGRAFIA}

Biermann F., A Slavic or a Viking town? The excavations at Wolin 1934/41 and their contemporary interpretation, w: Scandinavian Culture in Medieval Poland, Wrocław 2013.

Biernat C., Spór archiwalny polsko-gdańsko-niemiecki w okresie międzywojennym, 19191939, Warszawa 1969.

Biliński P., Władysław Konopczyński 1880-1952. Człowiek i dzieło, Kraków 2017.

Błahij K., Ostatnia tajemnica zatopionych bogów, Warszawa 1971.

Bodniak S., Życiorys własny, Pamiętnik Biblioteki Kórnickiej 5, 1955.

Broszat M., 200 lat niemieckiej polityki wobec Polski, thum. E. Kaczmarczyk, W. Leder, Warszawa 1999.

Burleigh M., Albert Brackmann \& the Nazi adjustment of history, History Today 3, 1987.

Burleigh M., Germany Turns Eastwards. A Study of Ostforschung in the Third Reich, Cambridge 1988.

Chałupczak H., Powstanie i działalność polskich placówek konsularnych w okresie między-

108 M. S z u k ała, Pruskie archiwa, s. 152.

109 Tamże, s. 166.

110 Podróż w dniach 2-3 XII 1938 r. potwierdza adnotacja na liście J. Kostrzewskiego do

O. Kunkla w sprawie przyjazdu jego asystentów (ADAMNSz, teczka nr 1949, s. 145). Niestety o tej podróży nie wiadomo nic więcej.

111 Dokument ten, obecnie zaginiony, a do niedawna przechowywany w ADAMNSz, cytuje

K. Bła hij, Ostatnia tajemnica, s. 71.

112 W. Filipow i a k, M. Gi erke, K. Ko k o r a, M. K ow a ls k a, Zaginiona dokumentacja, s. 27-28.

113 ADAMNSz, teczka nr 1759, s. 31 (list K. Wildego do O. Kunkla, 30 VIII 1935). Do podobnych wniosków odnośnie do działań W. Unverzagta w Santoku doszła S. G r u n w a ld, „Die Aufteilung der Burgen”, s. 255.

114 Szczecin, Archiwum Państwowe, Pomorskie Muzeum Krajowe w Szczecinie, sygn. 12, s. 35 (pismo Urzędu Nadprezydenta Prowincji Pomorze do O. Kunkla, 1 IX 1936).

115 Tamże, s. 49 (pismo O. Kunkla do Deutsche Kongres-Zentrale, 2 IX 1936, Tgb. 36/1546). O. Kunkel swoją wprawę planował także na zaledwie 3 dni. 
wojennym (ze szczególnym uwzględnieniem pogranicza polsko-niemiecko-czechosłowackiego), w: Konsulaty na pograniczu polsko-niemieckim i polsko-czechosłowackim w latach 1918-1939, Katowice 2004.

Chwaliszewski R., Kierownicy konsulatu Rzeczypospolitej Polskiej w Pile w latach 19221939, Rocznik Nadnotecki 15-16, 1984-1985.

Chwaliszewski R., Z działalności konsulatu Rzeczpospolitej Polskiej w Pile w latach 19221939, Piła 1984.

Deutschland und Polen. Beiträge zu ihren geschichtlichen Beziehungen, Hrsg. A. Brackmann, München-Berlin 1933.

Filipowiak W., Gierke M., Kokora K., Kowalska M., Zaginiona dokumentacja z przedwojennych badań archeologicznych w Wolinie, w: Kościoły w dobie chrystianizacji, Szczecin 2016 (Wolińskie Spotkania Mediewistyczne III).

Gąssowski J., Z dziejów polskiej archeologii, Warszawa 1970.

Górski K., Autobiografia naukowa, red. W. Sieradzan, Toruń 2003.

Grunwald S., „Die Aufteilung der Burgen auf die Geschichte wird eine Änderung erfahren müssen". Zur Geschichte der Zantoch-Idee, Acta Praehistorica et Archaeologica 41, 2009.

Hackmann J., Deutsche Ostforschung und Geschichtswissenschaft, w: Deutsche Ostforschung und polnische Westforschung im Spannungsfeld von Wissenschaft und Politik. Disziplinen im Vergleich, t. I, Osnabrück-Poznań 2002.

Inachin K.T., Pommern als Grenzprovinz in der Agitation der politischen Rechten 19191933, w: Pogranicze polsko-niemieckie. Przeszłość - teraźniejszość - przyszłość, Szczecin 2001.

Jażdżewski K., Pamiętniki. Wspomnienia polskiego archeologa z XX wieku, Łódź 1995.

Kaczmarek J. E., Organizacja badań i ochrony zabytków archeologicznych w Poznaniu (17201958), Poznań 1996.

Kaczmarek J. E., Prinke A., Żywot długi, pracowity i spełniony. Profesor Józef Kostrzewski (1885-1969) - prehistoryk, patriota, Europejczyk, Poznań (w druku).

Kalisz Z., Stanisław Bodniak - historyk i bibliotekarz, Pamiętnik Biblioteki Kórnickiej 19, 1982.

Kazimierz Tymieniecki (1887-1968). Dorobek i miejsce w mediewistyce polskiej, red. J. Strzelczyk, Poznań 1990.

Kessler W., Zum Bild Pommerns in der nationalsozialistischen Publizistik. Einige Bemerkungen am Beispiel der Zeitschrift „Das Bollwerk”, w: Państwo i społeczeństwo na Pomorzu Zachodnim do 1945 r., Szczecin 1997.

Kisielewski J., Ziemia gromadzi prochy, Warszawa 1990.

Koczy L., Jomsborg, Kwartalnik Historyczny 46, 1932, z. 3-4.

Koczy L., Polska i Skandynawia za pierwszych Piastów, Poznań 1934.

Koczy L., Źródła staronordyckie do dziejów Słowian, Slavia Occidentalis 11, 1932.

Koczy L., Związki małżeńskie Piastów ze Skandynawami, Slavia Occidentalis 11, 1932.

Kokowski A., Kreismuseum Flatow (Złotów) - Provinzmuseum Schneidemühl (Piła). Nieznane dzieje archeologicznych zbiorów muzealnych w dawnej prowincji Grenzmark Posen-Westpreussen, Fontes Archaeologici Posnanienses 47, 2011.

Kokowski A., Niemirowski W., Na tropie zaginionych odkryć. Archeologia w świetle doniesień prasowych z dawnej prowincji Grenzmark - Posen-Westpreußen / Auf den Spuren von verlorenen Entdeckungen die Archäologie im Spiegel der Presse der Ehemaligen Provinz Grenzmark - Posen-Westpreußen, Lublin 2016.

Kokowski A., Robert Liebig. Archeolog amator z Wielkopolski / Einer Amateurarchäologe aus Großpolen, Lublin 2016.

Kostrzewski J., Dzieje polskich badań prehistorycznych, Poznań 1949.

Kostrzewski J., Słowiańska królowa Bałtyku wyjrzała z pod ziemi, Kurier Poznański nr 101 (2 III 1935).

Kostrzewski J., Z mego życia. Pamiętnik, Wrocław 1970.

Kostrzewski J., Zagadka Winety rozwiązana. Co znaleziono pod brukiem rynku w Wolinie, Ilustracja Polska 1936, nr 45. 
Kowalski K., Kwerenda źródeł kultury pucharów lejkowatych przeprowadzona przez Konrada Jażdżewskiego w 1931 roku na obszarze ówczesnej prowincji Pomorze, Materiały Zachodniopomorskie Nowa Seria 13, 2017.

Kowalski K., Filipowiak Wł., Dawne zbiory archeologiczne Muzeum Narodowego w Szczecinie, w: Zaginione - ocalone. Szczecińska kolekcja starożytności pomorskich, Szczecin 2012 .

Kozłowski M., Sprawa premiera Leona Kozłowskiego. Zdrajca czy ofiara?, Warszawa 2005 .

Kozłowski S. K., Kwiat królestwa. Archeologów polskich pokolenie trzecie, Warszawa-Łódź 2015 .

Kozłowski S. K., Włodzimierz Antoniewicz, profesor z Warszawy, Warszawa 2009.

Krzoska M., Für ein Polen an Oder und Ostsee. Zygmunt Wojciechowski (1900-1955) als Historiker und Publizist, Osnabrück 2003.

Leśny J., Józef Widajewicz, w: Wybitni historycy wielkopolscy, red. J. Strzelczyk, Poznań 2010.

Lew-Machniak A., Między otwartą wrogością a fasadową przyjaźnią. Heliodor Sztark - polski konsul w niemieckim Szczecinie, Szczecin 2016.

Mastalerz-Krystjańczuk M., Pomorze Zachodnie w polskiej nauce, publicystyce i działalności politycznej w latach 1919-1939, Słupsk 2013.

Migdalski P., Między nauką, mitem a propagandą. Przeszłość Wolina w polskich badaniach oraz w życiu małego miasta na ziemiach zachodnich w okresie Polski Ludowej, Wodzisław Śląski 2019 (w przygotowaniu).

Migdalski P., Słowiańszczyzna północno-zachodnia w historiografii polskiej, niemieckiej i duńskiej, Wodzisław Śląski 2019 (w druku).

Mroczko M., Polska myśl zachodnia 1918-1939 (Kształtowanie i upowszechnienie), Poznań 1986.

Nowak Z.H., Starania Karola Górskiego o dostęp do archiwów Gdańska i Królewca w latach 1933-1938, w: Polska i jej sąsiedzi w czasach najnowszych. Studia i materiały ofiarowane profesorowi Karolowi Grünbergowi w 70-lecie urodzin, Toruń 1995.

Papritz J., Koppe W., Vorwort, Jomsburg 1, 1937.

Piotrowska D., Biskupin - ideologie - kultura, w: Archeologia - kultura - ideologie, Biskupin-Wrocław 2004.

Piotrowski B., O Polskę nad Odrą i Bałtykiem. Myśl zachodnia i badania niemcoznawcze Uniwersytetu Poznańskiego, Poznań 1987.

Piskorski J.M., Herbert Ludat (1910-1993) - historyk Słowiańszczyzny Zachodniej i stosunków polsko-niemieckich, w: H. Ludat, Słowianie - Niemcy - Europa. Wybór prac, thum. J.M. Piskorski, Marburg-Poznań 2000.

Profesor Leon Kozłowski, red. S. K. Kozłowski, O. Sytnyk, Lwów-Warszawa 2010.

Pryt K., Befohlene Freundschaft. Die deutsch-polnische Kulturbeziehungen 1934-1939, Osnabrück 2010.

Schubart H., Die Vorgeschichtsforschung an der Universität Greifswald, w: Festschrift zur 500-Jahrfeier der Universität Greifswald, 17. 10. 1956, t. II, Greifswald 1956.

Skóra W., Konsulat Rzeczypospolitej Polskiej w Szczecinie w latach 1925-1939, Słupsk 2001.

Smogorzewski K., Spojrzenie w zaranie Państwa Polskiego, Gazeta Polska nr 356 (24 XII 1935).

Stanisławski B. M., Jómswikingowie z Wolina-Jómsborga - studium archeologiczne przenikania kultury skandynawskiej na ziemie polskie, Wrocław 2013.

Stępiński W., Czasopiśmiennictwo historyczne Pomorza Zachodniego od drugiej połowy XX wieku po czasy współczesne, Zapiski Historyczne 63, 1998, z. 2.

Stępiński W., Prasa Pomorza Zachodniego wobec stosunków Rzeszy z II Rzeczpospolitą w latach 1933-1935. Między kontynuacją a zwrotem, w: Deklaracja polsko-niemiecka o niestosowaniu przemocy z dnia 26 stycznia 1934 r. z perspektywy Polski i Europy W siedemdziesiątą rocznicę podpisania, Toruń 2005. 
Szukała M., Martin Wehrmann i Otto Kunkel - ich rola w nauce i kulturze Szczecina końca XIX i pierwszej połowy XX wieku, w: Muzealnicy, archiwiści i bibliotekarze szczecińscy w XX wieku, Szczecin 2002.

Szukała M., Pruskie archiwa państwowe a niemieckie badania wschodnie (deutsche Ostforschung) w okresie międzywojennym XX wieku (1918-1939). Między nauką a politycznym zaangażowaniem, Szczecin-Warszawa 2011.

Tymieniecki K., Sprawozdanie z ekspedycji naukowej do Wolina w dniach 28 i 29 października 1935, Roczniki Historyczne 11, 1935.

Tymieniecki K., W sprawie Wolina, Roczniki Historyczne 11, 1935.

Widajewicz J., Położenie Jomsborga, Kwartalnik Historyczny 48, 1934.

Widajewicz J., Przy ujściu Odry w drugiej połowie X wieku, Poznań 1935.

Wilde K. A., Die Bedeutung der Grabung Wollin 1934, Stettin 1939.

Wojciechowski M., Polsko-niemiecka deklaracja o nieagresji z 26 stycznia 1934 r., Katowice 1963.

Wojciechowski Z., Jeszcze słowo o Wolinie, Roczniki Historyczne 11, 1935.

Wojciechowski Z., Kilka słów o Wolinie, Roczniki Historyczne 10, 1934.

„Wołyń” u ujścia Odry, Kurier Poznański, nr 151 (31 III 1935).

Zadrożny T., Kajetan i inni (2). Oskarżające Gerharda pisanie, Cenne, Bezcenne, utracone $2009, \mathrm{nr} 4$.

Zernack K., „Niemcy i Wschód” jako problem badań historycznych w Berlinie, w: tenże, Niemcy - Polska. Z dziejów trudnego dialogu historiograficznego, tłum. Ł. Musiał, Poznań 2006.

\section{A visit of Polish scholars in Szczecin and Wolin in 1935}

\section{Summary}

The paper presents - on the basis of never before used source materials of both Polish and German provenience, from the archives in Szczecin and Warsaw - an expedition of Polish historians (Kazimierz Tymieniecki, Zygmunt Wojciechowski, Leon Koczy, Józef Widajewicz) and an archaeologist (Józef Kostrzewski) to Szczecin and Wolin, where intensive systematic archaeological excavations started in 1934. The Polish scholars learned about the Wolin excavations thanks to Zygmunt Wojciechowski, who was on vacation at the Pomeranian seaside. He informed the Polish consulate about it and diplomatic arrangements were initiated in order to organise a visit of Polish scholars as a study expedition. The consul Heliodor Sztark started corresponding not only with the Polish Ministry of Foreign Affairs, but also with leading Polish prehistorians, including Włodzimierz Antoniewicz, the Prime Minister Leon Kozłowski, Józef Kostrzewski, and the supervisor of the Wolin excavations, the director of the Pomeranian Regional Museum, Otto Kunkel. Finally, after over a year of correspondence exchange and preparations, the above mentioned scholars came from Poznań to Szczecin and Wolin on 28-29 October 1935. The expedition was widely related by Polish press and both sides informed their superiors. The expedition fitted well in the period of relaxation of political relation, but also of scholarly arguments between Poland and Germany after signing the Polish-German declaration on refraining from using force from 26 January 1934. Courtesy gestures were shown on both sides, but the source materials indicate that at that time the impact of politics on scholarly research and its use was immense. 